\title{
Production and Characterization of Emulsified Fish Mortadella From Nile Tilapia (Oreochromus niloticus)
}

\author{
Heloísa Maria Ângelo Jerônimo ${ }^{\mathrm{a}}$, Maria Elieidy Gomes de Oliveira ${ }^{\mathrm{b}}$, Carlos \\ Eduardo Vasconcelos de Oliveira ${ }^{\mathrm{c}}$, Natália Ferrão Castelo Branco Melo ${ }^{\mathrm{d}}$, \\ Alex Poeta Casali ${ }^{\mathrm{e}}$, Antônio Rosendo da Costa ${ }^{\mathrm{e}}$, Aryane Ribeiro da Silva ${ }^{\mathrm{a}}$, \\ Ricácia de Sousa Silva ${ }^{a}$, And TÂnia Lúcia Montenegro Stamford ${ }^{d^{*}}$ \\ ${ }^{\text {a }}$ Laboratory of Food Technology and Analysis, Education and Health Center, Federal University of Campina \\ Grande, 58.175-000, Cuité, Paraíba, Brazil \\ b Post-Graduate Program in Nutrition, Department of Nutrition, Health Sciences Center, Federal University of \\ Paraíba, 58051-900, João Pessoa, Paraíba, Brazil \\ ${ }^{\mathrm{c}}$ Laboratory of Bromatology, Department of Nutrition, Health Sciences Center, Federal University of Paraíba, \\ 58051-900, João Pessoa, Paraíba, Brazil \\ ${ }^{d}$ Post-Graduate Program in Nutrition, Department of Nutrition, Health Sciences Center, Federal University of \\ Pernambuco, 50670-901, Recife, Pernambuco, Brazil \\ ${ }^{\mathrm{e}}$ Laboratory of Farming and Aquaculture Products, Department of Agroindustrial Management and \\ Technology, Human, Social and Agrarian Sciences Center, Federal University of Paraíba, 58.220-000, \\ Bananeiras, Paraíba, Brazil
${ }^{*}$ Corresponding author
tlmstamford@yahoo.com.br \\ TEL.: +55-81-32684611
}

Received: 30 January 2020; Published online: 18 April 2021

\begin{abstract}
This study produced fish mortadella from Mechanically Separated Meat (MSM) of Nile tilapia added with animal fat. Three formulations were developed: M1 (MSM - $89 \%$ and $5 \%$ pork fat), M2 (MSM - $84 \%$ and $10 \%$ pork fat) and M3 (MSM - $79 \%$ and $15 \%$ pork fat). The elaborated products were tested for technological, physical, physico-chemical, microbiological and sensory parameters. The results showed that the fish mortadella were microbiologically stable with a particular texture for an emulsified meat product, attractive colour and characteristic flavour. All formulations met the expected identity and quality requirements. They also achieved good acceptance by the judges, in which formulation M1 may be highlighted for presenting an emulsion stability of $97 \%$, higher protein content $(18.09 \%)$ and lower lipids $(16.31 \%)$. In addition, it also reached higher mean scores for texture attributes and purchase intent. Therefore, it is possible to prepare fish mortadellas from tilapia MSM using less animal fat.
\end{abstract}

Keywords: Fish waste; Fish mortadella; Oreochromus niloticus; Sensory analysis; Waste processing

\section{Introduction}

Fish are a highly beneficial food to human nutrition as they are a source of vitamins and minerals, and contain a high proportion of long chain

Copyright (C)2021 ISEKI-Food Association (IFA) polyunsaturated fatty acids and all the essential amino acids for humans (Fernandes et al., 2014; Sleder et al., 2015; Zotos \& Vouzanidou, 2012). The Nile tilapia (Oreochromis niloticus) can be 
highlighted as being among the most cultivated species in the world. It has high productivity, good adaptation to diverse environments, good acceptance in the consumer market, reduced fat content and excellent fillet yield (FAO, 2017; Liu et al., 2015; Olopade, Taiwo, Lamidi \& Awonaike, 2016). On the other hand, the mechanical filleting process generates approximately 70 $\%$ by-products (processing waste or discarded meat), resulting in large fish meat and oil losses. The head, carcass and guts constitute $54 \%$ of the waste, while the skin represents $10 \%$. In general, these residues are destined to produce tilapia flour and oil used in manufacturing animal feed for fish, pigs and birds (Campagnoli de Oliveira Filho, Netto, Ramos, Trindade \& Macedo Viegas, 2010).

Several studies have been carried out with tilapia and its by-products to promote and improve the sustainability of the fish industry, seeking to increase its consumption and maximize its use. One of its by-products is Mechanically Separated Meat (MSM), which has been used in developing new products such as emulsified meat products (sausages or mortadella, nuggets, surimi, fishburgers, etc.) It also stands out for having good unsaturated fat content which can reduce the addition of animal fat without causing sensory changes to the texture, flavour or consistency of the elaborated products (dos Santos Fogaca, Otani, De Gaspari Portella, Alves dos Santos-Filho \& Sant' Ana, 2015; Ferreira Silva Bartolomeu et al., 2014).

In view of the recognized technological and market potential of emulsified meat products, the present study had the objective of producing an emulsified fish mortadela from Nile tilapia (Oreochromus niloticus) MSM added to different animal fat contents, aiming to obtain a differentiated product with high biological value and low fat content.

\section{Materials and Methods}

\subsection{Tilapia slaughter and MSM production}

The fish were obtained from an association of tilapia farmers from the city of Bananeiras/PB,
Brazil. They were purged in clean water for 24 hours, captured in the early hours of the morning, then transported in plastic boxes where they were desensitized by thermal stunning. After respiratory activity ceased they were hung on hooks, where they were then eviscerated, and the fish were flaked, washed and filleted following a linear flow. Next, the carcasses were crushed using a pulping machine (Bresi ${ }^{\circledR}, 60 \mathrm{~kg} / \mathrm{h}, 1 / 2$, hp motor, stainless steel), thereby obtaining the MSM. The MSM was then vacuum packed into $2.0 \mathrm{~kg}$ polyethylene bags, labelled, and frozen (at -18 ${ }^{\circ} \mathrm{C}$ ) until it was used in the production of fish mortadella.

\subsection{Nile tilapia (Oreochromis niloticus) MSM quality assessment}

Acidity, pH, moisture, dry matter, ash, protein (AOAC, 2012) and lipid (Floch, 1957) parameters were evaluated. The microbiological quality of the MSM was verified based on coliform counts at $45^{\circ} \mathrm{C} \mathrm{MPN} / \mathrm{g}$, coagulase-positive Staphylococcus CFU/g, sulphite-reducing Clostridium sp. $\mathrm{CFU} / \mathrm{g}$, Salmonella sp./25 g and molds and yeasts (APHA, 2001).

\subsection{Preparation of fish mortadella}

The fish mortadella was prepared as described by Ferreira Silva Bartolomeu et al. (2014) and Campagnoli de Oliveira Filho, Netto et al. (2010). The present study used different concentrations of tilapia MSM and refined pork fat (Table 1). The other ingredients used in preparing the fish mortadella were added in the same concentrations to all treatments (Table 1 ).

A high-yielding tabletop cutter (METVISA ${ }^{\circledR}$, CUT $2.5 \mathrm{~L} ; 1 / 3 \mathrm{hp}$ motor) was used for preparing the fish mortadella according to the flowchart and the steps described below (Figure 1).

Comminution began with the MSM, salt, curing agents and polyphosphate for thirty seconds. Ice water, pork fat, and other ingredients were added at thirty-second intervals until the formation of a paste (similar to a pâté), at a controlled temperature with a skewer thermometer (INCOTERM ${ }^{\circledR}$ Digital thermometer) with a 
Fish mortadella from Nile tilapia $\mid 205$

Table 1: Formulations of emulsified fish mortadella with different concentrations of tilapia MSM and pork fat

\begin{tabular}{lrrr}
\hline & \multicolumn{3}{c}{ Concentrations (\%) } \\
\cline { 2 - 4 } Ingredients & M1 & M2 & M3 \\
\hline MSM & 74.00 & 69.00 & 64.00 \\
Pork lard & 5.00 & 10.00 & 15.00 \\
ISP & 5.00 & 5.00 & 5.00 \\
Ice/cold water & 8.00 & 8.00 & 8.00 \\
Polyphosphate & 0.30 & 0.30 & 0.30 \\
Curing salts & 0.20 & 0.20 & 0.20 \\
Antioxidant & 0.60 & 0.60 & 0.60 \\
Starch & 4.00 & 4.00 & 4.00 \\
Mortadella seasoning & 0.70 & 0.70 & 0.70 \\
Flavour enhancement & 0.15 & 0.15 & 0.15 \\
Black pepper & 0.05 & 0.05 & 0.05 \\
Garlic powder & 0.25 & 0.25 & 0.25 \\
Smoke aroma & 0.50 & 0.50 & 0.50 \\
Salt & 1.25 & 1.25 & 1.25 \\
Total & 1 & 1 & 1 \\
\hline MSM - Mechanically Separated & &
\end{tabular}

MSM - Mechanically Separated Meat;

ISP - Isolated Soybean Protein;

M1 - Fish mortadella with $5 \%$ pork fat;

M2 - Fish mortadella with $10 \%$ pork fat;

M3 - Fish mortadella with $15 \%$ pork fat

maximum temperature of $12{ }^{\circ} \mathrm{C}$ at the end of comminution.

The obtained pâté was packed into artificial shrinkable casings using a manual stuffer (METVISA ${ }^{\circledR}$, EL.10). The fish mortadella was cooked in moist heat until it reached an internal temperature of $72 \pm 1{ }^{\circ} \mathrm{C}$, monitored with the aid of a thermometer equipped with a thermocouple, Digital Cooking Thermometer). After the cooking was finished, the mortadella was submitted to thermal shock by immersing it in ice water for 15 minutes until it reached temperatures between 15 to $20{ }^{\circ} \mathrm{C}$, and then it was vacuum packed.

\subsection{Evaluation of technological properties}

\section{Emulsion stability - ES}

Emulsion stability was performed according to the method described by Parks and Carpenter
(1987). Emulsion stability values were obtained by calculating the weight loss and its percentage using the following formula:

$$
\% \text { Emulsion stability }=100-\% \text { loss }
$$

\section{Texture profile analysis}

Hardness, springiness, cohesiveness, chewiness, fracturability, gumminess, adhesiveness and resilience parameters, were evaluated using the TA XT-2i texture analyser with Exponent ${ }^{\circledR}$ software (Stable Micro Systems, Godalming, UK) with a probe of $35 \mathrm{~mm}$ diameter (SMS P/36R) moving at a constant speed of $0.8 \mathrm{~mm} / \mathrm{s}$, according to Bourne (2002).

A Warner Braztler accessory (3 $\mathrm{mm}$ thick) was used to measure shear force at a test speed of $200 \mathrm{~mm} / \mathrm{min}$ (Andres, Garcia, Zaritzky \& Califano, 2006). Mean and standard deviation were calculated from 16 determinations (Lin \& Chao, 2001).

IJFS | April 2021 | Volume $10 \mid$ pages 203-220 


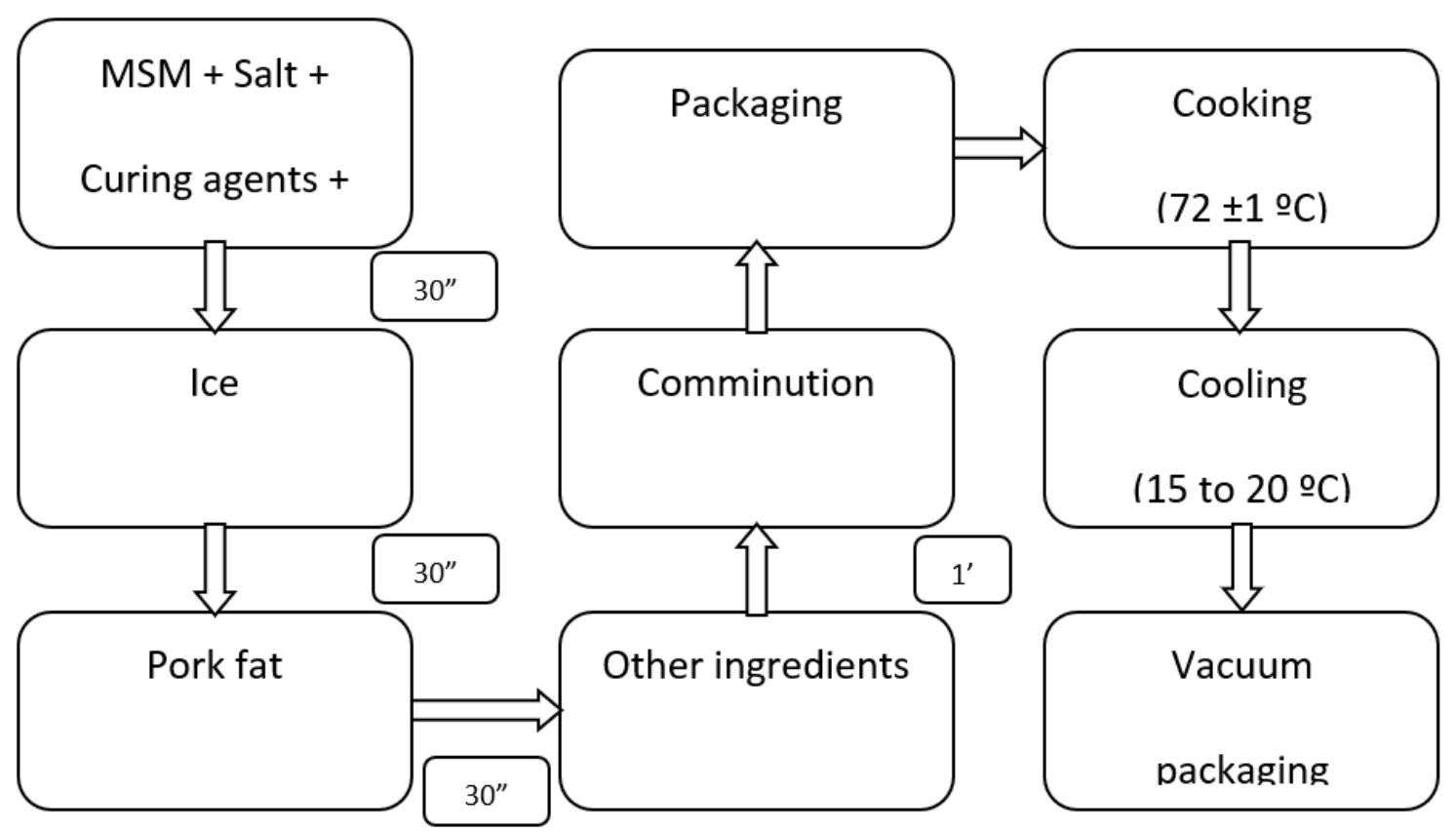

Figure 1: Flowchart of fish mortadella preparation

\section{Physical and physical-chemical analyzes}

The analyses carried out were: water activity $\left(\mathrm{a}_{w}\right), \mathrm{pH}$, normal acidity, moisture, dry matter, protein, ash (AOAC, 2012), chloride according to the Mohr Method, calcium content determined by EDTA volumetry (AOAC, 2012) and lipids (Floch, 1957). Water Retention Capacity (WRC) was evaluated according to the methodology by Grau (1953).

Lipid oxidation was evaluated by determining the peroxide index method $(\mathrm{mEq} / \mathrm{kg})$ based on the measurement of thiobarbituric acid reactive substances (TBARS) according to Ganhao, Estevez and Morcuende (2011) and based on Brasil (1999). The peroxide concentration was given by $\mathrm{mEq} / \mathrm{kg}$ of the sample.

The instrumental colour of each fish mortadella was determined according to the methodology described by Abularach, Rocha and de Felício (1998), using a digital Minolta ${ }^{\circledR}$ colorimeter (Model CR-300, Minolta, Osaka, Japan). Luminosity parameters $\left(\mathrm{L}^{*}\right)$, green $(-) / \operatorname{red}(+)\left(\mathrm{a}^{*}\right)$ and blue $(-)$ /yellow $(+)\left(\mathrm{b}^{*}\right)$ were determined ac- cording to the specifications of the Commision Internationale de L'éclairage (CIE, 1986).

\section{Microbiological analyzes}

Coliform counts at $45^{\circ} \mathrm{C} \mathrm{MPN} / \mathrm{g}$, coagulasepositive Staphylococcus CFU/g, sulphitereducing Clostridium $\mathrm{CFU} / \mathrm{g}$, and checking for Salmonella sp./25 g counts were carried out as recommended for fish mortadella and for counting molds and yeasts (APHA, 2001).

\section{Sensorial analysis}

After approval of the project by the Research Ethics Committee under number 821.481, the fish mortadella was submitted for sensory acceptance, intention to purchase and order preference (Faria \& Yotsuyanagi, 2002; Meilgaard, Carr \& Civille, 1991; Stone \& Sidel, 1993).

One hundred twenty-six (126) untrained consumers aged between 20 and 50 years of age who liked to consume fish and emulsified fish mortadella were recruited. These tasters evaluated 
the samples in individual booths with white artificial lighting, away from noise and odours, and at previously established times.

The fish mortadella was offered sliced, refrigerated and codified, accompanied by salt crackers and a glass of water. Attributes of appearance, colour, aroma, flavour (specific mortadella flavour), flavour (specific fish flavour), texture and overall assessment were evaluated using a mixed nine-point structured hedonic scale $(1=$ I greatly disliked it; $9=\mathrm{I}$ liked it a lot). Next, the tasters were asked to indicate their intention to purchase, also using a mixed five-point hedonic scale ( 1 = I would never buy it; $5=$ I would buy it). The samples were considered accepted when they obtained a mean $\geq 5.0$ (equivalent to the hedonic term "I neither liked it nor disliked it"). An Acceptability Index (AI) was also calculated according to the equation:

$$
A I(\%)=A \times 100 / B
$$

In which, $\mathrm{A}=$ average score obtained for the product and $\mathrm{B}=$ maximum score given to the product. An AI with good repercussion was considered $\geq 70 \%$ (Teixeira, Meinert \& Barbetta, 1987).

The overall preference for the different fish mortadella was also evaluated through the preference order test in decreasing order (from the most preferred to the least preferred).

\subsection{Statistical analysis}

Data were submitted to analysis of variance (ANOVA) and Tukey test at $5 \%$ probability $(\mathrm{p}<0.05)$ for comparison of means using the STATISTICA 7.0 program (Statistica, 2005). Principal component analysis (PCA) was performed for the different groups of variables and based on the correlation matrix of these variables in order to provide graphical representation of the significant sensory attributes.

The results of sensory preference ordering tests were analyzed according to the Friedman test using the Newell-MacFarlane table (Faria \& Yotsuyanagi, 2002).

\section{Results and Discussion}

\subsection{Nile tilapia (Oreochromis niloticus) MSM quality assessment}

The percentage values found for the MSM in the quality assessment are presented in the table 2. Regarding the $\mathrm{pH}$, similar values in analyzing MSM from fish were reported by CavenaghiAltemio, Alcade and Fonseca (2013) of 7.10, and Calil Angelini et al. (2013) of 6.9. There is no legal parameter for the $\mathrm{pH}$ limit of fish MSM; however, for fresh fish a maximum value of 6.8 is imposed for this parameter (Brasil, 1952). The results of this study are justified by the fact that fish have a close to neutral $\mathrm{pH}$. In addition, the processing for obtaining MSM disintegrates tissue, which exposes muscle fibres to degrading substances and may facilitate an increase in $\mathrm{pH}$ values, according to Pereda et al. (2005).

Moisture, ash and protein values were close to those found by Dallabona et al. (2013) $(71.0 \%$, $1.22 \%$ and $15.37 \%$ ), by Campagnoli de Oliveira Filho, Favaro-Trindade, Trindade, de Carvalho Balieiro and Macedo Viegas (2010) (74.45\%, $1.14 \%$ and $12.76 \%$ ), and by dos Santos Fogaca et al. (2015) (73.87\% and $15.87 \%$ ) for moisture and protein, respectively.

The values for lipids were different from those found by Cavenaghi-Altemio et al. (2013) of 2.53 \%, dos Santos Fogaca et al. (2015) of $7.62 \%$, and by Kirschnik and Macedo-Viegas (2009) of $2.91 \%$, due to the fact that in the present study, the MSM had the presence of the ventral musculature which contains the highest fat content, around $15 \%$.

The results complied with the parameters determined by the relevant legislation Brasil (2000), which recommends a minimum protein content of $12 \%$ and a maximum fat content of 30 $\%$, confirming that tilapia MSM is a good protein source, and thus demonstrating its viability for use in protein products of good biological value Rebouças, Rodrigues, de Castro and Vieira (2012). 


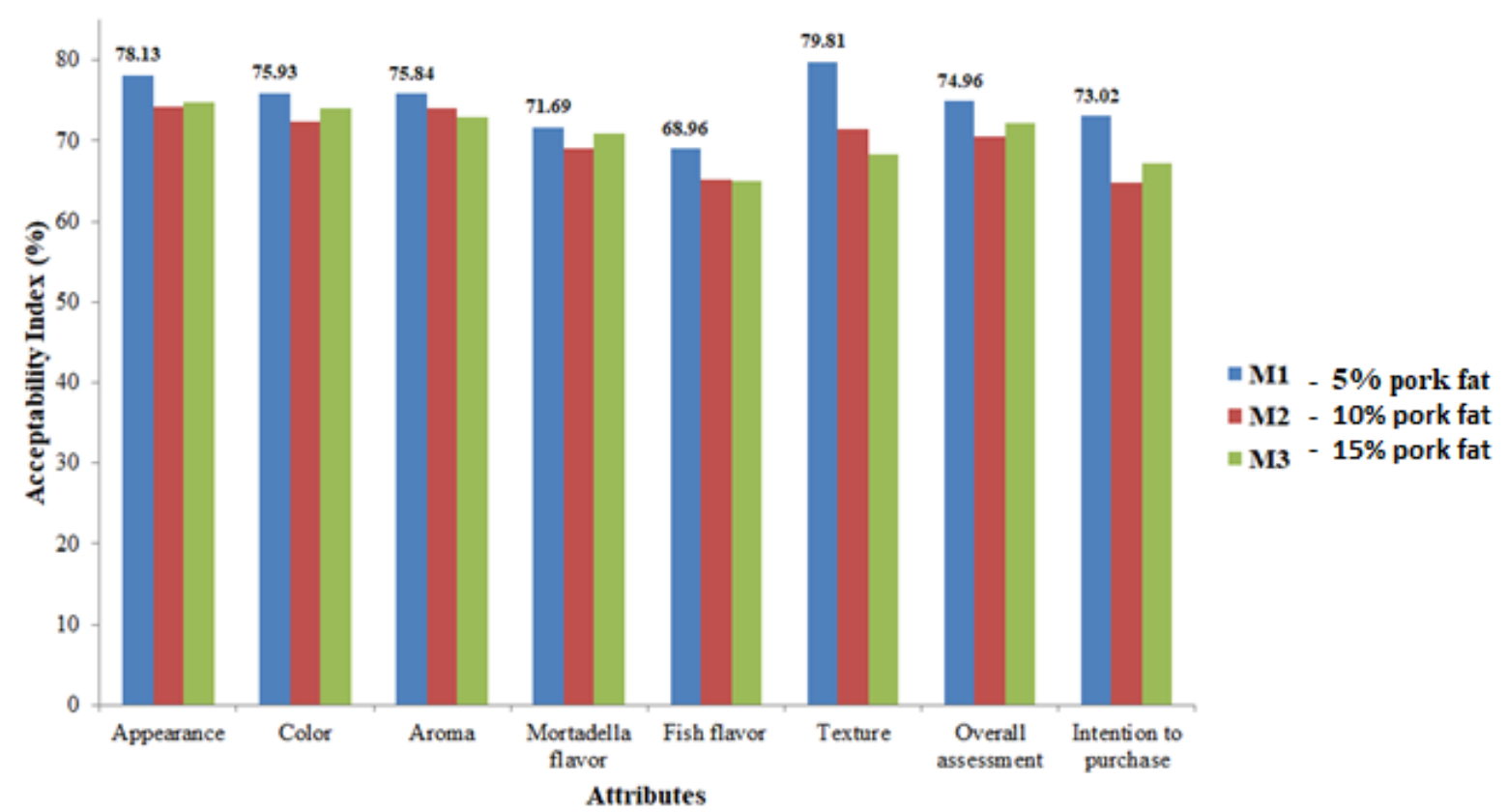

Figure 2: Acceptability index of the sensory attributes of fish mortadella with different concentrations of pork fat

Table 2: Mean values obtained in the physical and physicochemical analyses of fish mortadella with different concentrations of tilapia MSM and pork fat.

\begin{tabular}{lccc}
\hline & \multicolumn{3}{c}{ Mortadella } \\
\cline { 2 - 4 } Variable & M1 & M2 & M3 \\
\hline $\mathrm{a}_{w}$ & $0.96 \pm 0.00^{a}$ & $0.96 \pm 0.00^{a}$ & $0.96 \pm 0.00^{a}$ \\
$\mathrm{pH}$ & $7.11 \pm 0.00^{a}$ & $7.13 \pm 0.01^{a}$ & $7.16 \pm 0.05^{a}$ \\
WRC $^{*}(\%)$ & $57.93 \pm 2.21^{a}$ & $58.51 \pm 3.11^{a}$ & $58.15 \pm 2.79^{a}$ \\
Normal acidity (\%) & $4.12 \pm 0.14^{a}$ & $3.80 \pm 0.01^{a}$ & $3.68 \pm 0.13^{a}$ \\
Moisture (\%) & $63.63 \pm 0.01^{a}$ & $59.58 \pm 0.05^{b}$ & $56.73 \pm 0.05^{c}$ \\
Dry matter (\%) & $36.37 \pm 0.01^{c}$ & $40.42 \pm 0.05^{b}$ & $43.27 \pm 0.05^{a}$ \\
Ashes (\%) & $3.90 \pm 0.20^{a}$ & $4.31 \pm 0.15^{a}$ & $3.85 \pm 0.46^{a}$ \\
Proteins (\%) & $18.09 \pm 0.01^{a}$ & $17.46 \pm 0.02^{b}$ & $16.54 \pm 0.03^{c}$ \\
Lipids (\%) & $16.31 \pm 0.00^{c}$ & $19.84 \pm 0.05^{b}$ & $24.38 \pm 0.02^{a}$ \\
Sodium chloride (\%) & $1.88 \pm 0.03^{c}$ & $2.35 \pm 0.02^{a}$ & $2.17 \pm 0.00^{b}$ \\
Calcium (\%) & $0.32 \pm 0.00^{a}$ & $0.28 \pm 0.00^{b}$ & $0.21 \pm 0.00^{c}$ \\
\hline
\end{tabular}

Means \pm standard deviation with different letters on the same line differed by Tukey's test $(\mathrm{p}<0.05)$. M1 - Fish mortadella with $5 \%$ pork fat; M2 - Fish mortadella with $10 \%$ pork fat; M3 - Fish mortadella with $15 \%$ pork fat. ${ }^{*}$ WRC - Water Retention Capacity. 
Fish mortadella from Nile tilapia $\mid 209$

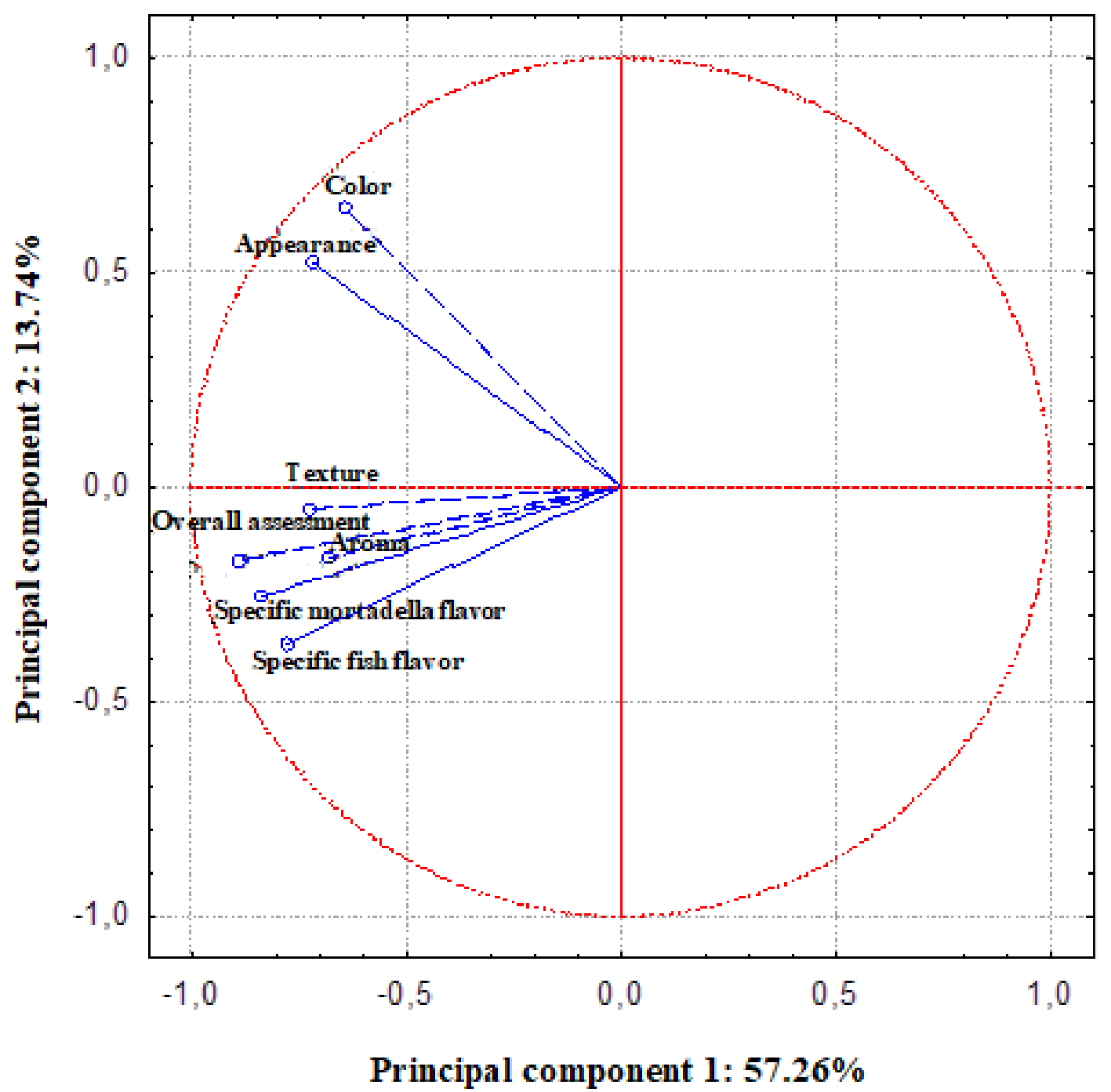

Figure 3: Projection of the PCA of the attributes in the sensory analysis of samples of fish mortadella with different concentrations of tilapia MSM and pork fat 


\subsection{Evaluation of the technological properties of the fish mortadella}

The values obtained from the emulsion stability, shear force and texture profile evaluations are shown in Table 3.

\section{Emulsion stability}

In this study, the results for emulsion stability (ES) $(97.03 ; 93.30$ and $91.74 \%)$ in the different fish mortadella treatments, M1, M2 and M3, respectively, were influenced by the fat content, so that the higher the pork fat concentration added, the lower the ES $(\mathrm{p}<0.05)$. It is also important to point out that the higher amount of protein provided better emulsion stability results (Table 3) agreeing with the literature data. In evaluating sausages made from MSM and fish surimi, Yousefi and Moosavi-Nasab (2014) concluded that crude protein values of around $19 \%$ resulted in products with greater hardness and better gel consistency.

The findings of this study were attributed to the balance achieved for the protein concentrations (Table 3), which contributed to the formation of a good emulsion.

\section{Texture profile analysis - TPA}

Shear force and instrumental texture profile may vary according to the amount of water, proteins and fats found in the sample (Cengiz \& Gokoglu, 2007; Cofrades, Guerra, Carballo, FernandezMartin \& Colmenero, 2000). It was observed (Table 3) that as the MSM percentage was reduced and that of pork fat increased along with a consequent reduction in protein content, a significant decrease $(\mathrm{p}<0.05)$ in the other parameters was also observed, with the exception of adhesiveness which increased $(\mathrm{p}<0.05)$ with the increase in fat concentration.

Campagnoli de Oliveira Filho, Favaro-Trindade et al. (2010) observed an increase in the softness of the sausages made with increasing amounts of Nile tilapia MSM - 0 to $100 \%$. Similarly, it was observed in the present study that the softness improved (as decreases in the hardness and shear force) with the increase in fat concentration instead of MSM. These data were expected, considering that higher amounts of fat are responsible for a reduction in texture parameters, especially when fat increases are followed by a decrease in protein and water contents in the formulations, as observed in the present study (Dincer \& Cakli, 2010; Hashemi \& Jafarpour, 2016; Kin et al., 2013). The results in the present study agreed with Sleder et al. (2015) who also found that a reduction in the amount of protein and an increase in the amount of fat significantly decrease the shear force from $8.4(\mathrm{~N})$ to $5.92(\mathrm{~N})$ in sausages without added fat and with $95.5 \%$ of tambaqui meat (Colossoma macropomum); and with $9 \%$ fat and $86.5 \%$ tambaqui meat, respectively. In evaluating sausages prepared with fish MSM of fish surimi, Yousefi and Moosavi-Nasab (2014) found that those made with MSM presented greater shear force than those prepared with surimi $-1.75 \mathrm{~N} \mathrm{~cm}^{2}$ and $1.08 \mathrm{~N} \mathrm{~cm}^{2}$, respectively, and concluded that it is the greater amount of protein present in the MSM rather than its quality that determined the best texture profile for MSM fish sausages.

According to Hedrick, Aberle, Forrest, Judge and Merkel (1994), meat protein, represented mainly by myofibrillar proteins (actin and myosin), is the main factor responsible for the hardness in emulsified products. Colmenero, Barreto, Mota and Carballo (1995) also confirmed this relationship in their experiments with sausages, verifying that the higher the protein content, the greater the firmness of the final product; a similar characteristic was observed with the fish mortadella in this research.

Adhesiveness is high in traditional emulsified meat products (Campos, Gonçalves, Mori \& Gasparetto, 1989). However, the partial or total replacement of meaty matter by MSM and the inclusion of fats contribute to forming products with a softer consistency, as in this study (Table $3)$. As the fat content increased in the formulations, the products had a softer consistency, tending to disintegrate during slicing.

\section{Instrumental colour analysis}

The parameters L* (luminosity), a* (red/green colour intensity) and $b^{*}$ (intensity of yellow/blue 
Fish mortadella from Nile tilapia $\mid 211$

Table 3: Mean values obtained in the emulsion stability, shear force and texture profile (TPA) analyses of fish mortadella with different concentrations of tilapia MSM and pork fat.

\begin{tabular}{lccc}
\hline \multirow{2}{*}{ Technological parameters } & \multicolumn{3}{c}{ Mortadella } \\
\cline { 2 - 4 } & M1 & M2 & M3 \\
\hline Emulsion stability (\%) & $97.03 \pm 0.00^{a}$ & $93.30 \pm 0.00^{b}$ & $91.74 \pm 0.00^{c}$ \\
\hline Shear force (N) & $3.73 \pm 0.01^{a}$ & $2.47 \pm 0.02^{b}$ & $1.25 \pm 0.02^{c}$ \\
\hline Texture profile (TPA) & & & \\
\hline Hardness (kg) & $1.87 \pm 0.06^{a}$ & $1.20 \pm 0.04^{b}$ & $0.82 \pm 0.01^{c}$ \\
Springiness (mm) & $0.80 \pm 0.03^{a}$ & $0.67 \pm 0.04^{b}$ & $0.49 \pm 0.08^{c}$ \\
Cohesiveness (kg) & $0.53 \pm 0.01^{a}$ & $0.47 \pm 0.01^{b}$ & $0.35 \pm 0.02^{c}$ \\
Chewiness (g.mm) & $0.81 \pm 0.08^{a}$ & $0.41 \pm 0.03^{b}$ & $0.22 \pm 0.02^{c}$ \\
Fracturability (kg) & $2.03 \pm 0.02^{a}$ & $0.94 \pm 0.03^{b}$ & $0.61 \pm 0.04^{c}$ \\
Gumminess (kg) & $1.01 \pm 0.06^{a}$ & $0.58 \pm 0.08^{b}$ & $0.37 \pm 0.06^{c}$ \\
Resilience (kg) & $0.35 \pm 0.07^{a}$ & $0.21 \pm 0.01^{b}$ & $0.11 \pm 0.05^{c}$ \\
Adhesiveness (kg.s) & $-0.78 \pm 0.06^{c}$ & $-0.34 \pm 0.07^{b}$ & $-0.12 \pm 0.08^{a}$ \\
\hline
\end{tabular}

Means \pm standard deviation with different letters on the same line differed by Tukey's test $(\mathrm{p}<0.05)$. M1 - Fish mortadella with 5\% pork fat; M2 - Fish mortadella with $10 \%$ pork fat; M3 - Fish mortadella with $15 \%$ pork fat.

colour) are shown in Table 4.

Colour is correlated with the acceptance of food products (Dincer \& Cakli, 2010; Ferreira Silva Bartolomeu et al., 2014). It was observed that by decreasing the MSM content and increasing the fat content, the luminosity value $\left(\mathrm{L}^{*}\right)$ was increased between samples M1 and M2, as well as between M1 and M3 ( $\mathrm{p}<0.05)$, confirming the theory that moisture and lipid contents have a considerable influence on $\mathrm{L}^{*}$ values. The $\mathrm{L}^{*}$ results were below those determined by Moreira, Visentainer, de Souza and Matsushita (2001), who found an $\mathrm{L}^{*}$ value of 72.28 in a study with sausage formulated with tilapia filets, and close to those found by do Amaral et al. (2015), who also verified that the fat content positively affected luminosity indices in pork sausages as the fat content increased with values between 55 and 63.

Dantas Guerra et al. (2012) also found that the higher the fat content, the higher the $\mathrm{L}^{*}$ and $\mathrm{b}^{*}$ values, with values between 52.0 and $59.4\left(\mathrm{~L}^{*}\right)$ and 8.6 to $10.5\left(\mathrm{~b}^{*}\right)$ for sheepmeat mortadella prepared with different levels of pork fat ranging from 10 to $30 \%$, respectively. Similarly, differences were also found $(\mathrm{p}<0.05)$ in the present study for the $\mathrm{b}^{*}$ parameter when the fish mortadella with $5 \%$ pork fat was compared with the other formulations; and the fish mortadella with 10 and $15 \%$ fat in the formulation presented higher values for yellow colour intensity due to the higher fat percentage added to them.

There was no observed decrease for the $\mathrm{a}^{*}$ values when the amount of MSM also decreased. This occurred due to the fact that we chose to use isolated soybean protein to improve the acceptance of the fish mortadella, which probably contributed to an increase in the red colour between the M1 fish mortadella and the other formulations ( $\mathrm{p}$ $<0.05)$.

\subsection{Evaluation of physical and physical-chemical characteristics of fish mortadella}

The physical and physico-chemical parameters of the fish mortadella are shown in Table 2.

The results of water activity $\left(\mathrm{a}_{w}\right)$ obtained for the fish mortadella were equal $(\mathrm{p}>0.05)$, corresponding to 0.96 and above 0.85 , which is the 
$212 \mid$ Jerônimo et al.

Table 4: Mean values obtained in the instrumental color analyse of fish mortadella with different concentrations of tilapia MSM and pork fat.

\begin{tabular}{lccc}
\hline & \multicolumn{3}{c}{ Mortadella } \\
\cline { 2 - 4 } Technological parameter & M1 & M2 & M3 \\
\hline Instrumental Colour & & \\
\hline $\mathrm{L}^{*}$ & $9.44 \pm 0.26^{b}$ & $65.21 \pm 0.13^{a}$ & $65.31 \pm 0.09^{a}$ \\
$\mathrm{a}^{*}$ & $10.76 \pm 0.06^{b}$ & $11.21 \pm 0.16^{a}$ & $11.35 \pm 0.05^{a}$ \\
$\mathrm{~b}^{*}$ & $9.23 \pm 0.17^{a}$ & $10.76 \pm 0.31^{a}$ \\
\hline Means \pm standard deviation with different letters on the same line differed \\
by Tukey's test (p<0.05). M1 - Fish mortadella with 5\% pork fat; M2 - Fish \\
mortadella with 10\% pork fat; M3 - Fish mortadella with 15\% pork fat.
\end{tabular}

limit for considering them as foods with high water activity. This characteristic favours the proliferation of microorganisms, indicating the need to keep these products under refrigeration during storage, as well as the adoption of other measures during processing to inhibit microbial proliferation. These results are similar to those established by Fellows (2009) for a cooked cured product (0.95); by Ferreira Silva Bartolomeu et al. (2014) who determined $\mathrm{a}_{w}$ of 0.98 for a smoked tilapia mortadella; and to the values reported by Campagnoli de Oliveira Filho, Favaro-Trindade et al. (2010) of 0.98 for tilapia MSM sausage; and also those by Dallabona et al. (2013) corresponding to 0.97-0.98 for tilapia MSM smoked sausages under different heat treatment conditions and packaging.

The $\mathrm{pH}$ values were similar to the results obtained for MSM. Other researchers such as Sleder et al. (2015) reported values lower than those found in this study, with mean $\mathrm{pH}$ values of 6.6 in tambaqui sausages (Colossoma macropomum); Cavenaghi-Altemio et al. (2013) determined mean values of 6.76 in analysing sausages produced from protein concentrates of tilapia; and (Mélo et al., 2011) found mean values of 6.39 in tilapia MSM mortadella.

In the present study, the $\mathrm{pH}$ values can be justified since the material used was raw, which already has higher values of $\mathrm{pH}$, as well as sodium polyphosphate in the formulation (Mélo et al., 2011) which has a pH between 9.5 and 10.5. There were no significant differences in the WRC values between the different fish mortadella for- mulatios (Table 2). However, these results were lower than those reported by Sleder et al. (2015). These authors identified WRC values ranging between 71.83 and $74.71 \%$ in tambaqui mortadella with different fat percentages. Despite the low WRC values in this study, there was no damage to the structure of the formed emulsion, such as fat coalescence or syneresis, and it did not affect the sensory evaluations.

Regarding to moisture content, similar results have been reported for different types of emulsified meat products with MSM. For example, Sleder et al. (2015) observed a decrease in moisture values $(72.73 \%, 71.05 \%$ and $68.82 \%)$ as the fat content in the tambaqui sausage formulation increased $(0 \%, 4.5 \%$ and $9 \%$, respectively). The results found in this study were similar to those of Yousefi and Moosavi-Nasab (2014), who studied MSM sausages or tilapia suprimi and found moisture values of 65.46 and $67.45 \%$, respectively; and those of Mélo et al. (2011), who analysed the moisture of tilapia MSM mortadella and determined decreasing values between 75.90 and 59.38 $\%$ as the fat percentage varied between 0 to $20 \%$, a similar behaviour to that found in the present investigation.

Despite the variations observed according to the added pork fat content, all formulations prepared in this study remained within the limits of moisture recommended by legislation Brasil (2000), which is $65 \%$. This differed from other studies with other types of emulsified meat products in which the average moisture of their products was above those quantified here, such as Campagnoli 
de Oliveira Filho, Favaro-Trindade et al. (2010), who produced tilapia MSM sausages with a mean moisture content of $70.75 \%$; and CavenaghiAltemio et al. (2013), who processed emulsified meat products with concentrated tilapia protein and found average moisture values of $75.83 \%$.

Increasing pork fat content caused the dry matter content to increase significantly $(\mathrm{p}<0.05)$ in all formulations (Table 2). In addition to the increasing pork fat concentration in the formulations, the values were in line with the composition of the MSM extracted from the abdominal muscle, which contained considerable adiposity (Bordignon et al., 2010; de Oliveira, Henriques Lourenco, Sousa, Peixoto Joele \& do Amaral Ribeiro, 2015). It is worth mentioning that fish fat is a source of omega-3, a fatty acid beneficial to consumer health (Menegazzo, Petenucci \& Fonseca, 2016; Moreira et al., 2001; Nestel, 2000).

The values for ash represented the overall mineral content of the formulations, which did not differ significantly between them $(p>0.05)$ despite the fat percentage and MSM variations. Similar results were found by Sleder et al. (2015), who found quantities between 3.86 and $4.20 \%$ in tambaqui sausages with different fat contents; by Dallabona et al. (2013), who found values between $3.44 \%$ in pasteurized sausage and $3.97 \%$ in smoked sausage; and by Campagnoli de Oliveira Filho, Netto et al. (2010), who obtained similar results $(3.40 \%)$ in cooked emulsified meat products. The high levels of ash occurred due to the addition of ingredients such as salt and additives, as well as the incorporation of bone fragments to the mass.

The protein and fat content of the fish mortadella varied significantly $(\mathrm{p}<0.05)$. Consequently, a concomitant decrease in protein content and increase in lipid content was observed for M1, M2 and M3. The importance of these nutrients and their equilibrium in forming a good emulsion and maintenance of their shelf life stability is known, in addition to the importance of the amount of proteins for greater firmness of the formed gel (Yousefi \& Moosavi-Nasab, 2014). Thus, having a balanced percentage in the amount of proteins and fats is of fundamental importance to ensure obtaining a product with all the desirable characteristics present.
The fish mortadella formulated in the present study are products of high biological value and with reduced fat content, in addition to being a source of unsaturated fat. This is especially true for the M1 formulation, which presented a percentage of $18.09 \%$ for proteins and $16.31 \%$ for fats (almost half of that recommended by the legislation, which is at most $30 \%$ ). These results reinforced the relevance of this new product being proposed for the food industry.

In relation to sodium chloride, a statistical difference $(\mathrm{p}<0.05)$ between the treatments was observed (Table 2), probably due to the fact that the processing is semi-industrial and carried out in batches of $500 \mathrm{~g}$ each, which may have caused differences in the homogenization pattern of the ingredients.

Calcium levels are well below that recommended by the legislation of a maximum of $0.90 \%$ (Brasil, 2000). As expected, it was also observed that calcium values decreased $(\mathrm{p}<0.05)$ as MSM was replaced by animal fat in the formulations. This fact is due to the reduction of the tilapia filleting residues, which contain bone fragments in their composition (calcium source).

Although there are no legal standards limiting the levels of lipid oxidation expressed as peroxide value, values above $1.51 \mathrm{mg}$ of $\mathrm{mEq} / \mathrm{kg}$ and $3.0 \mathrm{mEq} / \mathrm{kg}$ in fish and fish products, respectively, are classified as unacceptable (Campagnoli de Oliveira Filho, Favaro-Trindade et al., 2010). Thus, it is essential to verify the presence of oxidation in emulsified meat products through an evaluation of the peroxide index $(\mathrm{mEq} / \mathrm{kg})$, considering that it is possible to have important alterations in the food depending on its presence in the product due to lipid oxidation.

No changes to this parameter were found in this study with results of $0.0 \mathrm{mEq} / \mathrm{kg}$, which showed that all the processing was in accordance with what is recommended by Good Manufacturing Practice (Brasil, 1997), and unlike other studies such as Ferreira Silva Bartolomeu et al. (2014), who found levels of $0.99 \mathrm{mEq} / \mathrm{kg}$ in tilapia mortadella; Calil Angelini et al. (2013), who quantified a mean of $0.22 \mathrm{mEq} / \mathrm{kg}$ in tilapia quenelles; and Campagnoli de Oliveira Filho, Favaro-Trindade et al. (2010), who found levels between $0.67 \mathrm{mEq} / \mathrm{kg}$ and $1.24 \mathrm{mEq} / \mathrm{kg}$ in sausages with percentages of tilapia MSM ranging 
from 0 to $100 \%$.

\subsection{Microbiological evaluation of MSM and fish mortadella}

All the formulations were in accordance with RDC No. 12 of January 2001 - National Health Surveillance Agency (Brasil. Agência Nacional de Vigilância Sanitária. Collegiate Board Resolution No. 12 of 2001. Approves the technical regulation on microbiological standards for food. Diário Oficial da República Federativa do Brasil, Poder Executivo, Brasília, DF, Brazil (in Portuguese)., 2001), and no viable cells were found for any of the microorganisms that were tested for. These results agree with those found by Ferreira Silva Bartolomeu et al. (2014), who formulated smoked tilapia MSM mortadella; and those of Campagnoli de Oliveira Filho, Netto et al. (2010) and Dallabona et al. (2013), who also elaborated tilapia MSM mortadella and tested its microbiological quality. These findings affirmed the feasibility of producing this type of emulsified meat product.

\subsection{Sensory evaluation}

Only the attributes texture and intention to purchase differed significantly among the treatments $(\mathrm{p}<0.05)$ (Table 5). This occurred due to the correlation of the data for the instrumental texture and sensory texture. The increase in the fat content in the formulations corresponded to a reduction in the instrumental texture, which probably contributed to the reduction in the scores attributed to sensory texture $(\mathrm{p}<0.05)$.

Nonetheless, all formulations presented mean scores equal to or above 6.0 (Table 5), demonstrating that the fish mortadella was sensorially well-accepted for this parameter; a behaviour also similar to that found by Rahman, Al-Waili, Guizani and Kasapis (2007), who observed a correlation between instrumental and sensory texture in fish sausages.

A positive correlation between instrumental hardness and fracturability with the sensory texture was observed, although they were higher for the M1 formulation (Table 3). There was good sensory acceptance for the texture attrib- ute, presenting a higher mean score of $7.3(\mathrm{p}<$ 0.05 ) when compared to the other formulations. These findings were similar to the data found by Rahman et al. (2007), which showed that instrumental hardness is highly correlated with the sensory hardness of fish sausage.

The sensory scores for colour, odour, flavour and texture were higher than from studies with other emulsified products such as by Campagnoli de Oliveira Filho, Netto et al. (2010) and Cavenaghi-Altemio et al. (2013). In the present study, scores were similar to the results of Ferreira Silva Bartolomeu et al. (2014), who evaluated smoked tilapia MSM mortadella and found scores ranging from 7 (I moderately liked it) to 8 (I liked it a lot).

In addition, despite being a new product to the consumers, it was found that their overall acceptance varied between the hedonic terms "I slightly liked it" and "I liked it a lot", with a mean score ranging from $6.8( \pm 1.5)$ to $7.1( \pm 1.4)$. Campagnoli de Oliveira Filho, Favaro-Trindade et al. (2010) found lower results than these for the overall assessment of sausages prepared with increasing percentages of MSM (0 to $100 \%$ ), with scores ranging from 6.1 to 5.0 .

In an emulsion, the lack of balance between the amounts of fat and protein can harm its sensory evaluation (Yousefi \& Moosavi-Nasab, 2014), which was not observed in this study considering that all formulations generally obtained average scores for the sensory attributes between 6 and 7. The M1 formulation stood out with scores for the appearance attributes, mortadella flavour, texture and overall assessment between 7 and 8, whose hedonic terms correspond to "I moderately liked it" and "I liked it a lot".

These scores were reinforced by the comments made by the judges of which 105 out of the 126 tasters made some kind of comment with an emphasis on taste and texture attributes, with about $32.38 \%$ and $10.47 \%$ reporting that the samples presented "pleasant taste" and "pleasant texture", respectively. The other comments were basically summarized as: "strong and/or smoky flavour" (13.33\%), "fishy taste" (7.61 \%), "pleasant smell" (5.7\%), among others.

Other important data relates to the purchase intention, whose attributed scores ranged from the hedonic terms of 3 ("I would perhaps buy 
Fish mortadella from Nile tilapia $\mid 215$

Table 5: Mean scores of the sensory acceptance and purchase intention tests performed with of fish mortadella with different concentrations of tilapia MSM and pork fat.

\begin{tabular}{lccc}
\hline \multirow{2}{*}{ Attributes } & \multicolumn{3}{c}{ Mortadella } \\
\cline { 2 - 4 } & M1 & M2 & M3 \\
\hline Appearance & $7.0 \pm 1.5^{a}$ & $6.7 \pm 1.6^{a}$ & $6.7 \pm 1.6^{a}$ \\
Colour & $6.8 \pm 1.6^{a}$ & $6.5 \pm 1.7^{a}$ & $6.7 \pm 1.8^{a}$ \\
Aroma & $6.8 \pm 1.8^{a}$ & $6.7 \pm 1.7^{a}$ & $6.6 \pm 1.7^{a}$ \\
Specific mortadella flavour & $7.0 \pm 1.5^{a}$ & $6.8 \pm 1.5^{a}$ & $6.9 \pm 1.5^{a}$ \\
Specific fish flavour & $6.8 \pm 1.4^{a}$ & $6.7 \pm 1.4^{a}$ & $6.5 \pm 1.5^{a}$ \\
Texture & $7.3 \pm 1.4^{a}$ & $6.6 \pm 1.7^{b}$ & $6.0 \pm 1.1^{c}$ \\
Overall assessment & $7.1 \pm 1.4^{a}$ & $6.8 \pm 1.5^{a}$ & $6.9 \pm 1.5^{a}$ \\
Intention to purchase & $3.9 \pm 1.1^{a}$ & $3.2 \pm 1.3^{b}$ & $3.0 \pm 1.0^{c}$ \\
\hline
\end{tabular}

Means \pm standard deviation with different letters on the same line differed by Tukey's test $(\mathrm{p}<0.05)$. M1 - Fish mortadella with $5 \%$ pork fat; M2 - Fish mortadella with $10 \%$ pork fat; M3 - Fish mortadella with $15 \%$ pork fat.

Table 6: Contribution to the formation of the principal component of the attributes evaluated in the sensorial analysis of mortadella samples.

\begin{tabular}{lcc}
\hline \multirow{2}{*}{ Analyzed Attributes } & \multicolumn{2}{c}{ Principal Components } \\
\cline { 2 - 3 } & $\mathbf{1}$ & $\mathbf{2}$ \\
\hline Appearance & -0.716 & 0.526 \\
Colour & -0.646 & 0.653 \\
Aroma & -0.681 & -0.167 \\
Specific mortadella flavour & -0.836 & -0.256 \\
Specific fish flavour & -0.776 & -0.367 \\
Texture & -0.723 & -0.052 \\
Overall assessment & -0.889 & -0.168 \\
\hline
\end{tabular}

Table 7: Distribution of grades according to the ordination of general preference by the judges $(\mathrm{n}=126)$ in the sensorial analysis of fish mortadella with different concentrations of tilapia MSM and pork fat.

\begin{tabular}{llllc}
\hline \multirow{2}{*}{ Mortadella } & \multicolumn{2}{l}{ Number of Judges per Order* } & \\
\cline { 2 - 4 } & 1 & 2 & 3 & Sum of orders** \\
\hline M1 & 34 & 33 & 59 & $277^{a}$ \\
M2 & 55 & 44 & 27 & $224^{b}$ \\
M3 & 57 & 44 & 25 & $220^{b}$ \\
\hline
\end{tabular}

$* 1=$ least preferred, $3=$ most preferred.

$* *$ Sum of the orders of each sample $=(1 \times$ number of judges $)+(2 \times$ number of judges $+\left(3 \mathrm{x} \mathrm{n}^{o}\right.$ judges $)$. a, b - lower case letters indicate the significant differences between of the mortadellas $(\mathrm{p}<0.05)$ by the Friedman test. M1 - Fish mortadella with $5 \%$ pork fat; M2 - Fish mortadella with $10 \%$ pork fat; M3 - Fish mortadella with $15 \%$ pork fat. 
it/maybe not buy it") and 5 ("I would buy it"), with emphasis on the sample prepared with $5 \%$ pork fat in its formulation which had a higher mean score $(\mathrm{p}<0.05)$ when compared to the other formulations.

Figure 2 shows the acceptability indexes (AI) for the fish mortadella with different concentrations of tilapia MSM and pork fat. According to Teixeira et al. (1987), it is necessary that a product reaches an AI of at least $70 \%$ in order for it to be considered as accepted in terms of sensory properties. Thus, it was observed that the AI for most of the attributes evaluated in the 3 fish mortadella formulations was above the minimum, with emphasis on the M1 fish mortadella.

The findings of this study agreed with Sleder et al. (2015) who verified that the best acceptance rates achieved in a study with tambaqui meat sausages were for those with lower pork fat content (9\%), with mean acceptance rates of $80 \%$ for all the tested parameters. Mélo et al. (2011) also found expressive acceptance levels (78.43\%) for the overall assessment attribute in fish mortadella prepared with corn oil and wheat fibre.

The intent to purchase test indicated a tendency of purchasing fish mortadella with $5 \%$ pork fat by a large proportion of the judges who participated in the sensory evaluations (73.02\%), as shown in Figure 2. Results similar to this were observed by Mélo et al. (2011), who reported an intent to purchase of $78.43 \%$ for mortadella prepared with MSM, corn oil and wheat fibre. The data obtained in this study indicate that there is room in the market for the product when it is available, increasing the supply of nutritious and healthier products.

The principal component analysis of the attributes in the sensory acceptance analysis of the fish mortadella was important to verify which attributes most contributed to differentiating the three formulations, which is shown in Figure 3.

In the PCA, the first main component contributed to $57.26 \%$ of the total variance and the second with $13.74 \%$, representing the first two factorial axes $(71 \%)$ in the total variance. If the first two or three components in a PCA accumulate a relatively high percentage of the total variance (generally above $70 \%$ ), they will satisfactorily explain the variability manifested among the samples (Mardia, 1979), and corroborate the data found in the present study.

For the Principal Component 2, colour and appearance were the attributes that most contributed to the group separation, as can be seen in Table 6 . Thus, for the target audience in question who analyzed the fish mortadella formulations under study, the most important quality to differentiate them from one another were these sensory attributes, with particularly little influence by the fish taste and mortadella flavour attributes.

The preference order test allowed us to determine which product was most preferred by a particular target audience through indications of the judges, ordering samples from the "most preferred" to "least preferred". The results for the preference order are shown in Table 7.

According to the statistical analysis, a significant difference $(\mathrm{p}<0.05)$ was observed between the M1 samples and the other formulations, in which the sample with $5 \%$ pork fat in its constitution was more preferred, most probably due to the texture attribute since it also presented a higher score $(\mathrm{p}<0.05)$ on the sensory acceptance test, also justifying its higher purchase intent.

When judges were asked which sensory characteristics they enjoyed the most in their preferred sample (M1), the majority of the answers were the flavour, the texture and the aroma. These attributes were similarly mentioned as characteristics that were not appreciated in the less preferred samples (M2 and M3).

\section{Conclusion}

In general, it can be affirmed that the different fish mortadella formulations had a good acceptability, with emphasis on the fish mortadella with $5 \%$ of pork fat which, in addition to exceeding the minimum limits predicted to be considered approved by the consumer public, also presented excellent results for technological, physical parameters and nutritional value. The development of this study proved that technological processing of an emulsified meat product from fish capture to its consumption is feasible from the logistic, sanitary, and technological points of view, among others. The use of MSM did not depreciate the 
quality of the final product. We suggest that the production of this mortadella can represent a viable technological alternative for the cluse of tilapia processing waste.

\section{Acknowledgements}

The authors would like to thank the Coordination for Improvement of Higher Education Personnel (CAPES, Brazil) for the financial support and scholarship granted to the first author.

\section{References}

Abularach, M. L. S., Rocha, C. E. \& de Felício, P. E. (1998). Características de qualidade do contrafilé (m. L. dorsi) de touros jovens da raça Nelore. Food Science and Technology, 18(2), 205-210.

Andres, S. C., Garcia, M. E., Zaritzky, N. E. \& Califano, A. (2006). Storage stability of low-fat chicken sausages. Journal of Food Engineering, 72(4), 311-319. doi:10.1016/ j.jfoodeng.2004.08.043

AOAC. (2012). Association of Official Analytical Chemists. Official methods of analysis of Association of Official Agricultural Chemists. (19th ed.). Association of Official Agricultural Chemists., Washighton, DC.

APHA. (2001). American Public Health Association. Compendium of methods for the microbiological examination of foods. (4th ed.). American Public Health Association., Washington, DC.

Bordignon, A. C., de Souza, B. E., Bohnenberger, L., Hilbig, C. C., Feiden, A. \& Boscolo, W. R. (2010). Preparation of nile tilapia (oreochromis niloticus) croquettes from msm and'v'cut fillet trim, and their physical, chemical, microbiological and sensory evaluation/elaboracao de croquete de tilapia do nilo (oreochromis niloticus) a partir de cms e aparas do corte em'v'do file e sua avaliacao fisico-quimica, microbiologica e sensorial. Acta Scientiarum. Animal Sciences, 32(1), 109-117.

Bourne, M. (2002). Food texture and viscosity: Concept and measurement. Elsevier.
Brasil. (1952). Presidência da República. Federal Decree No. 30.691 of 1952: Regulation of the industrial and sanitary inspection of products of animal origin. Diário Oficial da União, Brasília, DF, Brazil (in Portuguese).

Brasil. (1997). Ministério da Agricultura e do Abastecimento. Ordinance No. 368 of 1997: Technical regulation on the hygienic-sanitary conditions and of good practices of elaboration for establishments/industrializadores of foods. Diário Oficial da República Federativa do Brasil, Brasília, DF, Brazil (in Portuguese).

Brasil. (1999). Ministério da Agricultura e do Abastecimento. Normative Instruction No. 20 of 1999: Officializes official analytical methods for the control of meat products and their ingredients - salt and brine DAS. Diário Oficial da República Federativa do Brasil, Poder Executivo, Brasília, DF, Brazil (in Portuguese).

Brasil. (2000). Ministério da Agricultura e do Abastecimento. Normative Instruction No. 4 of 2000: Approves the Technical Regulations on the Identity and Quality of Mechanically Separated Meat, Mortadella, Sausage and Sausage. Diário Oficial da República Federativa do Brasil, Poder Executivo, Brasília, DF, Brazil (in Portuguese).

Brasil. Agência Nacional de Vigilância Sanitária. Collegiate Board Resolution No. 12 of 2001. Approves the technical regulation on microbiological standards for food. Diário Oficial da República Federativa do Brasil, Poder Executivo, Brasília, DF, Brazil (in Portuguese). (2001).

Calil Angelini, M. F., Galvao, J. A., Vieira, A. d. F., Savay-da-Silva, L. K., Shirahigue, L. D., Ribeiro Cabral, I. S., ... Oetterer, M. (2013). Shelf life and sensory assessment of tilapia quenelle during frozen storage. Pesquisa Agropecuaria Brasileira, 48(8), 1080-1087. doi:10 . 1590 / S0100 204X2013000800038

Campagnoli de Oliveira Filho, P. R., FavaroTrindade, C. S., Trindade, M. A., de Carvalho Balieiro, J. C. \& Macedo Viegas, E. M. (2010). Quality of sausage elaborated using minced Nile Tilapia subm- 
mitted to cold storage. Scientia Agricola, 67(2), 183-190. doi:10.1590 / S010390162010000200009

Campagnoli de Oliveira Filho, P. R., Netto, F. M., Ramos, K. K., Trindade, M. A. \& Macedo Viegas, E. M. (2010). Elaboration of Sausage Using Minced Fish of Nile Tilapia Filleting Waste. Brazilian Archives of Biology and Technology, 53(6), 1383-1391. doi:10 . 1590 / S1516 89132010000600015

Campos, S. D. S., Gonçalves, J. R., Mori, E. E. M. \& Gasparetto, C. A. (1989). Reologia e textura em alimentos. Campinas: ITAL.

Cavenaghi-Altemio, A. D., Alcade, L. B. \& Fonseca, G. G. (2013). Low-fat frankfurters from protein concentrates of tilapia viscera and mechanically separated tilapia meat. Food Science \& Nutrition, 1(6), 445-451.

Cengiz, E. \& Gokoglu, N. (2007). Effects of fat reduction and fat replacer addition on some quality characteristics of frankfurter-type sausages. International Journal of Food Science and Technology, 42(3), 366-372. doi:10.1111/j.1365-2621.2006.01357.x

CIE. (1986). Commission Internationale de l'Éclairage. Colourimetry. (2th. ed.). CIE Publication: Vienna, Austria.

Cofrades, S., Guerra, M. A., Carballo, J., Fernandez-Martin, F. \& Colmenero, F. J. (2000). Plasma protein and soy fiber content effect on bologna sausage properties as influenced by fat level. Journal of Food Science, 65(2), 281-287. doi:10.1111/j.13652621.2000.tb15994.x

Colmenero, F. J., Barreto, G., Mota, N. \& Carballo, J. (1995). Influence of protein and fat-content and cooking temperature on texture and sensory evaluation of bologna sausage. LWT - Food Science and Technology, 28(5), 481-487.

Dallabona, B. R., Karam, L. B., Wagner, R., Ferreira Silva Bartolomeu, D. A., Mikos, J. D., Phabiano Francisco, J. G., ... Kirschnik, P. G. (2013). Effect of heat treatment and packaging systems on the stability of fish sausage. Revista Brasileira de Zootecnia-Brazilian Journal of Animal
Science, 42(12), 835-843. doi:10 . $1590 /$ S1516-35982013001200001

Dantas Guerra, I. C., Lins de Albuquerque Meireles, B. R., dos Santos Felex, S. S., da Conceicao, M. L., de Souza, E. L., Benevides, S. D. \& Madruga, M. S. (2012). Spent lamb meat in the preparation of mortadella with different levels of pork fat. Ciencia Rural, 42(12), 2288-2294. doi:10. 1590/S0103-84782012005000113

de Oliveira, I. S., Henriques Lourenco, L. d. F., Sousa, C. L., Peixoto Joele, M. R. S. \& do Amaral Ribeiro, S. d. C. (2015). Composition of msm from brazilian catfish and technological properties of fish flour. Food Control, 50, 38-44. doi:10.1016/j.foodcont. 2014.08.018

Dincer, T. \& Cakli, S. (2010). Textural and sensory properties of fish sausage from rainbow trout. Journal of Aquatic Food Product Technology, 19(3), 238-248. doi:10.1080/ 10498850.2010.509539

do Amaral, D. S., Cardelle-Cobas, A., do Nascimento, B. M. S., Monteiro, M. J., Madruga, M. S. \& Pintado, M. M. E. (2015). Development of a low fat fresh pork sausage based on chitosan with health claims: Impact on the quality, functionality and shelf-life. Food \& Function, 6(8), 27682778. doi:10.1039/c5fo00303b

dos Santos Fogaca, F. H., Otani, F. S., De Gaspari Portella, C., Alves dos SantosFilho, L. G. \& Sant' Ana, L. S. (2015). Characterization of surimi from mechanically deboned tilapia meat and fishburger preparation. Semina - Ciencias Agrarias, 36(2), 765-775. doi:10.5433 / 1679 - 0359. 2015v36n2p765

FAO. (2017). Food Agriculture Organization. Anuario - Estadísticas de pesca y acuicultura Tablas resumen. Hojas de balance de alimentos 2013. Consumo aparente mundial por continentes. Retrieved from http: //www.fao.org/fishery/statistics/es

Faria, E. V. \& Yotsuyanagi, K. (2002). Sensory analysis techniques. ITAL-LAFISE, Campinas, SP, 116.

Fellows, P. J. (2009). Food processing technology: Principles and practice. Elsevier. 
Fernandes, C. E., da Silva Vasconcelos, M. A., Ribeiro, M. d. A., Sarubbo, L. A., Cardoso Andrade, S. A. \& de Melo Filho, A. B. (2014). Nutritional and lipid profiles in marine fish species from brazil. Food Chemistry, 160, 67-71. doi:10.1016/j.foodchem. 2014.03 .055

Ferreira Silva Bartolomeu, D. A., Waszczynskyj, N., Kirschnik, P. G., Dallabona, B. R., Oliveira Gomes da Costa, F. J. \& Leivas, C. L. (2014). Storage of vacuumpackaged smoked bologna sausage prepared from nile tilapia. Acta Scientiarum - Technology, 36(3), 561-567. doi:10.4025/ actascitechnol.v36i3.18263

Floch, J. (1957). A simple method for the isolation and purification of total lipids from animal tissues. J. biol. Chem. 226, 497-509.

Ganhao, R., Estevez, M. \& Morcuende, D. (2011). Suitability of the tba method for assessing lipid oxidation in a meat system with added phenolic-rich materials. Food Chemistry, 126(2), 772-778. doi:10.1016/j. foodchem.2010.11.064

Grau, R. (1953). Eine einfache methode zur bestimmung der wasserbindung im muskel. Naturwissenschaften, 40, 29-30.

Hashemi, A. \& Jafarpour, A. (2016). Rheological and microstructural properties of beef sausage batter formulated with fish fillet mince. Journal of food science and technology, 53(1), 601-610.

Hedrick, H. B., Aberle, E. D., Forrest, J. C., Judge, M. D. \& Merkel, R. A. (1994). Principles of meat science. kendall. Hunt Publishing Company, Dubuque, IA.

Kin, S., Morrison, R., Tolentino, A. C., Pham, A. J., Smith, B. S., Kim, T., ... Schilling, M. W. (2013). Sensory and physicochemical properties of smoked catfish sausages. Journal of Aquatic Food Product Technology, 22(5), 496-507. doi:10.1080/ 10498850.2012.668749

Kirschnik, P. G. \& Macedo-Viegas, E. M. (2009). Effect of washing and increase of additives on minced stability of nile tilapia (oreochromis niloticus) during storage under-18 degrees c. Ciencia e Tecnologia de Alimentos, 29(1), 200-206. doi:10.1590/S010120612009000100031
Lin, K. W. \& Chao, J. Y. (2001). Quality characteristics of reduced-fat chinese-style sausage as related to chitosan's molecular weight. Meat Science, 59(4), 343-351. doi:10.1016/S0309-1740(01)00084-5

Liu, Y., Ma, D.-h., Wang, X.-c., Liu, L.-p., Fan, Y.-X. \& Cao, J.-x. (2015). Prediction of chemical composition and geographical origin traceability of chinese export tilapia fillets products by near infrared reflectance spectroscopy. LWT - Food Science and Technology, 60(2, 2), 1214-1218. doi:10 . 1016/j.lwt.2014.09.009

Mardia, K. V. (1979). Multivariate analysis.

Meilgaard, M. C., Carr, B. T. \& Civille, G. V. (1991). Sensory evaluation techniques. CRC press.

Mélo, H. M. G., Moreira, R. T., DÁlmas, P. S., Maciel, M. I. S., Barbosa, J. M. \& Mendes, E. S. (2011). Feasibility of using mechanically deboned meat (mdm) of nile tilapia to produce an emulsified type of sausage. ARS Veterinaria, (27), 22-29.

Menegazzo, M. L., Petenucci, M. E. \& Fonseca, G. G. (2016). Quality assessment of nile tilapia and hybrid sorubim oils during low temperature storage. Food Bioscience, 16, 1-4. doi:10.1016/j.fbio.2016.06.003

Moreira, A. B., Visentainer, J. V., de Souza, N. E. \& Matsushita, M. (2001). Fatty acids profile and cholesterol contents of three brazilian brycon freshwater fishes. Journal of Food Composition and Analysis, 14(6), 565-574. doi:10.1006/jfca.2001.1025

Nestel, P. J. (2000). Fish oil and cardiovascular disease: Lipids and arterial function. American Journal of Clinical Nutrition, 71(1, S), 228S-231S. International Conference on Highly Unsaturated Fatty Acids in Nutrition and Disease Prevention, Barcelona, Spain.

Olopade, O. A., Taiwo, I. O., Lamidi, A. A. \& Awonaike, O. A. (2016). Proximate composition of nile tilapia (oreochromis niloticus) (linnaeus, 1758) and tilapia hybrid (red tilapia) from oyan lake, nigeria. Bulletin of University of Agricultural Sciences and Veterinary Medicine Clujnapoca-food Science and Technology, 73(1), 19-23. doi:10.15835/buasvmcn-fst:11973 
Parks, L. L. \& Carpenter, J. A. (1987). Functionality of six nonmeat proteins in meat emulsion systems. Journal of Food Science, 52(2), 271-274.

Pereda, J. A. O., Rodríguez, M. I. C., Álvarez, L. F., Sanz, M. L. G., Minguillón, G. D. G. F., Perales, L. H. \& Cortecero, M. D. S. (2005). Preservation by cold. In Technology of food: Foods of animal origin (p. 279). Porto Alegre Artmed.

Rahman, M. S., Al-Waili, H., Guizani, N. \& Kasapis, S. (2007). Instrumental-sensory evaluation of texture for fish sausage and its storage stability. Fisheries Science, 73(5), 1166-1176. doi:10.1111/j.1444-2906.2007. 01449.x

Rebouças, M. C., Rodrigues, M. d. C. P., de Castro, R. J. S. \& Vieira, J. M. M. (2012). Characterization of fish protein concentrate obtained from the Nile tilapia filleting residues. Semina: Ciências Agrárias, 33(2), 697-704.

Sleder, F., Cardoso, D. A., Savay-da-Silva, L. K., de Abreu, J. S., Soares de Oliveira, A. C. \& de Almeida Filho, E. S. (2015). Development and characterization of a tambaqui sausage. Ciencia e Agrotecnologia, 39(6), 604-612. doi:10 . 1590 / S1413 70542015000600007

Stone, H. \& Sidel, J. L. (1993). Sensory evaluation practices. San Dieco: Academic press.

Teixeira, E., Meinert, E. M. \& Barbetta, P. A. (1987). Sensory analysis of food. Florianópolis: UFSC.

Yousefi, A. \& Moosavi-Nasab, M. (2014). Textural and chemical attributes of minced fish sausages produced from talang queenfish (scomberoides commersonnianuus) minced and surimi. Iranian Journal of Fisheries Sciences, 13(1), 228-241.

Zotos, A. \& Vouzanidou, M. (2012). Seasonal changes in composition, fatty acid, cholesterol and mineral content of six highly commercial fish species of greece. Food science and technology international, 18(2), 139149 . 